\title{
DRUGIE NAUKOWE SEMINARIUM BIBLIJNE
}

W dniach od 5 do 7 września br. odbyło się w Warszawie w gmachu Arcybiskupiego Seminarium Duchowego drugie $\mathrm{z}$ kolei naukowe zebranlie polskich biblistów i profesorów Pisma św. Było ono wypelnieniem uchwały powziętej dwa lata temu w Lublinie podczas zjazdu profesorów Polskich Zakładów Teologicznych.

Powyższe Seminarium Naukowe zgromadziło 72 uczestników z całej Polski i zostało zorganizowane przez Ks. Ks. Profesorów Stanisława Ea cha i Feliksa Gryglewicza z KUL'u, za co należy się im serdeczne podziękowanie i uznanie. Charakter seminarium byl ściśle naukowy. Rzeczowo i starannie opracowane referaty jak również żywa dyskusja wniosły wiele cennego materialu do dotychczasowych badan nad Biblią, jak również rzuciły dużo światła na liczne dość jeszcze dziś skomplikowane i trudne do rozwiązania biblijne problemy.

Pierwszy dzień obrad rozpoczął się odśpiewaniem przez uczestników w kaplicy seminaryjnej hymnu ,Veni Creator" oraz odprawieniem mszy św. przez Ks. Prałata Ciechońskiego z Białegostoku. Z kolei Ks. Stanisław Ła ch Dziekan Wydz. Teol. KUL'u wygłosił na auli seminaryjnej inauguracyjne przemówienie dziękując między innymi Ks. Rektorowi Seminarium Wł: Mis i ołkowi, za udzielenie nam gościny , u siebie i umożliwienie w ten sposób odbycia naukowego seminarium. . Po powołaniu Prezydium, w skład którego weszli Księża Profesorowie: Waw. Gnute k, S. W rudyga i $K$. M is z c z a k, przystąpiono do wygłaszania referatów. W pierwszym dniu obrad wygłoszono następujące referaty: Ks. M. P eter z Poznania mówił na temat: „Istota natchnienia biblijnego $w$ dyskusji naukowej ostatniego dziesięciolecia" Ks. Walenty Prokulski TJ., zreferował naukę św. Pawła na ,Zbawcza sprawiedliwość Boża“, zaś Ks. Stanisław Grzy bek z Krakowa, podzielil się z zebranymi uwagami na temat „Autorstwo Pięcioksięgu we wspótczesnej katolickiej biblistyce". Popołudniu wygłosili swe referaty: Ks. Fel. Kłoniecki z Gniezna pt.: „Z aktualnej problematyki ewangelii Janowej" oraz Ks. Wład. Smerek a z Krakowa na temat: „Sledztwo jako stadium wstępne $w$ procesie Chrystusa Pana“. Po każdym referacie była długa i ożywiona dyskusja. Szczególne zainteresowanie zebranych Ks. Ks. Profesorów budziła kwestia natchnienia a zwłaszcza 
najnowsza hipoteza jaką postawil Ks. K. R a hner.TJ., w swej osttatnej pracy pt. Über die Schrift-Ispiration, Freiburg 1958. Ogólnie zebrani. wypowiedzieli sie przeciw przypuszczeniu $\mathrm{R}$ a hn e $\mathrm{r}$, jakoby natchnienie można identyfikować z kanonicznością danej księgi, w czym autorytatywną rolę odegrał pierwotny Kościól. Ks. W. P r ok uls k i dowiódz. w swym referacie, że sprawiedliwośc Boża wẹług św. Pawła, nie jest sprawiedliwością karzącą, ale objawiła się głównie w śmierci i zmartwychwstaniu Chrystusa. Z dyskusji nad referatem Ks. St: Grzybka należy podkreślić jednolitość poglądów wśród dyskutujących na temat powstania Pięcioksięgu ze źródeł oraz jego późniejszej redakcji.

Drugi dzień zaszczycił swą obecnością JEm. Najdostojniejszy Ks. Kard. Stefan W y s y ński, Prymas Polski, który odprawił w kaplicy seminaryjnej mszę św. w intencji Ks. Ks. Profesorów i ich Seminarium Naukowego, oraz wygłosił do zebranych podniosłą kenferencje. JEm: Ks. Prymas zaznaczył że, ponieważ "Verbum Dei non est alligatum i ,sermo currit" dlatego obowiązkiem naszym jest stałe poznawanie tego Słowa Bożego, zgłębianie jego treści i przekazywanie jej tym którzy sa głodni Boga i Jego Prawdy zawartej na kartach Biblii. Po przemówieniu JEm. Ks. Prymasa Ks. Dziekan Stan. Éa ch w imieniu wszystkich na auli seminaryjnej w gorących słowach podziękował Ks. Kardynałowi za jego życzliwość i serdeczność oraz zapewnil Go, że biblišci polscy dołożą wszelkich starań aby Pismo św. było przez wszystkich należycie szanowane, cenione i czytane. Z kolei przystápiono do wygłaszania referatów, przewidzianych programem zjazdu na dzień drugi.

Głos zabrał Ks. Wł. L ohn TJ., b. profesor z Gregorianum oraz prowincjał OO. Jezuitów który we wnikliwym swoim studium na temat „Forma literacka ewangelii św. Eukasza 9, 51-19, 28“; zachwycił wszystkich głębią swej erudycji, bogactwem zebranego i systematycznie przedstawionego materiału, oraz śmiałością proponowanych wniosków. Drugim referentem przed południem był Ks. R. Głodowski z Przemyślą, który mówił na temat "Mesjanizmu $w$ ksiegach mądrościowych". Popołudniu wygłoszono jeszcze dwa referaty a mianowicie: JE. Ks. Biskup H. Strąkowski zapoznał zebranych z problematyką księgi Jozuego, której przekład przygotowuje do mającego wyjść w „Pallottinum. komentarza Pisma św., zaś Ks. Jan Ła ch z Tarnowa mó vił o „Poczatkach profetyzmu izraelskiego w oparciu o księgi Samuela".

Zarówno pierwszego jak i drugiego dnia wieczorem uczestniczący w Naukowym Seminarium bibliści i profesorowie Pisma: św. wzięli udział w nabożeństwie w kaplicy seminaryjnej, oraz wysłuchali dwóch konferencji ascetycznych O. Augustyna Jankowskiego OSB., na temat wartości wiary i eucharystii w życiu kapłana.

W trzecim dniu obrad rano Msze św. celebrowal JE. Ks. Bp H. Strakowski i wygłoszono jeszcze dwa refenaty. Ks. Jan Drozd, Salwatorianin, mówił na temat ,Sens pelniejszy na tle encykliki Divino 
Afflante Spiritu", araz O. J. P a ś c i a k OP., profesor Angilicum z Rzymu na temat: „Swiętość Boga wedtug proroka Izajasza“. Po dyskusji jaka się wywiązala w związk z wygloszonymi referatami omówiono jeszcze szereg spraw administracyjnych związanych z odbywającym sie seminarium naukowym i urządzeniem następnego seminarium. Postanowiono wysłać telegramy do JEm. Ks. Kand. Stefana W y s z y ń s k i e g o, do JE. Ks. Bpa Michała Klepacza oraz dwóch najstarszych i najbardziej zasłużonych biblistów polskich: Ks. Prałata Piotra Stach a i Ks. Pralata Aleksego K la w ka. JEm. Ks. Prymas Kard. W y s z y ń s k i zaprosił wuszystkich biblistów na przyszły rok na odbycie Seminarium Naukowego do siebie da Gniezna, co zebrani przyjęli $z$ wielką radością. Ks. P. Granatowicz zrefenowal obecny stan prac związanych $z$ wydawaniem Komentarza do Pisma św. oraz zacręcił biblistów do żywej wspólpracy z wydawnictwem „Pallottinum“, które przejęło na siebie trud wydania tego komentarza. Z okazji 50-lecia kaplaństwa. Ks. Prałata P. Stacha, Redakcja Ruchu Biblijnego i Liturgicznego zobowiązała się wydać specjalny numer swego pisma, poświęcony pracy naukowej i twórczej dostojnego Jubilata. Będzie to numer 3/61. W związku z tym prosimy uczniów i wychowanków Ks. Prof. P. Stach a o nadsyłanie nam odpowiednilego materiału do powyższego numeru naszego pisma. Na zakonczenie Seminarium Naukowego wybrano Komitet Organizacyjny, który zajmie się przygotowaniem przyszłego zjazdu. W skład Komitetu weszli: Ks. Ks. Profesorowie, St. $€$ a c h Dziekan Wydz. Teol. KULu, Feliks Gryglewicz, St. Grzybek, Augustyn Jankow$s k i$ i Jan Stępien. Tematyka przyszłego seminarium naukowego będzie zapoznanie uczestników $\mathrm{z}$ najnowszymi osiągnięciami biblistyki w kraju i za granicą. 